\title{
Detecting privatization factors on promoting exports of steel companies
}

\author{
Seyed Mohsen SeyedAliAkbar ${ }^{a^{*}}$ and Mohammad Zaripour ${ }^{b}$
}

${ }^{a}$ Associate Professor, Department of Management and Accounting, South Tehran Branch, Islamic Azad University, Tehran, Iran

${ }^{b}$ Masters Student, Department of Industrial Engineering, South Tehran Branch, Islamic Azad University, Tehran, Iran

\section{H R O N I C L E}

Article history:

Received January 5, 2016

Received in revised format March

28,2016

Accepted April 12, 2016

Available online

April 14, 2016

Keywords:

Privatization

Export

Steel industry

\section{A B S T R A C T}

\begin{abstract}
Privatization is considered as the transfer of business from the government to the private sector. This process is often accomplished in an attempt to reduce the size of government, increase the productivity and export activities. There is no doubt that in an export oriented economy, government tries to promote expert based activities by making necessary changes on rules and regulations. This paper presents an empirical investigation to determine important factors on promoting export in Iran. The study designs a questionnaire in Likert scale and distributes it among some experts active in steel industry. Kaiser-Meyer-Olkin Measure of Sampling Adequacy is equal to 0.839 and Bartlett's Test of Sphericity yields an approximation Chi-Square value of $2485.02(\mathrm{Sig} .=0.000, \mathrm{df}=276)$. Using principle component analysis with Varimax rotation, the study has detected five important factors including human resources development, productivity management, marketing management, creating competitive environment and building necessary infrastructures, which influence the most on export activities.
\end{abstract}

\section{Introduction}

During the past few decades there have been significant efforts on building steel factories on economic scales in Iran. One of the important questions is to determine an economic scale for such plants which could also meet domestic demand. Jafari and Heidari (2011) did a survey to determine whether building small steel factories is more suitable or setting up giant steel industries to reach regional demands. They reported that building small steel plants based on the recent advances of technologies not only reduces the expenses of steel production but also eliminates the unnecessary transportation cost, which could lead to better competition and increase the productivity. Astier (1998) surveyed the effect of 82 minimills on US economy and recommended on using mini-mills for other industries. He added that a short period of plant commissioning could have several advantages. First, it is possible to take advantage of the new advances of technology. Second, the return on investment could be faster which is more favorable among short term investors. It also does not suffer from the massive layoff to cope with economic crises.

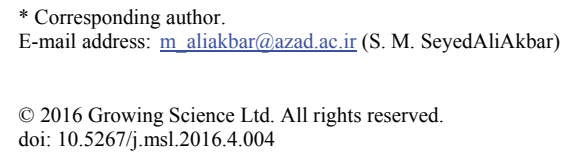


Export is among the most important activities for development of economies (Abedini \& Darabi, 2015; Ghasemi et al., 2015). Farooqui (2016) investigated the bilateral trade and economic growth between China and India and emphasized that export would be the biggest concern in development of India's economy. Habibzadeh et al. (2016) performed a survey to determine and rank important factors affecting entrepreneurial marketing to facilitate exports of small and medium enterprises (SMEs) in Iran. Using principle component analysis, they identified four factors including competitive intelligence, competitive advantage, external factors and internal factors to promote the export of SMEs.

Baheri et al. (2016) determined factors influencing on food industry for development of export activities. Using principle component analysis based on varimax rotation, they determined six factors including social opportunities, international opportunities, customer orientation, business opportunities, new technologies, organizational capabilities, commercialization of ideas on the development of export markets. Cadogan et al. (2002) contributed to some previous studies related to market orientation into the international arena by developing and testing hypotheses related to the antecedents to and consequences of market-oriented activities in firms' export operations. Export experience, export dependence and coordinating capabilities were determined in their study to be positively related to export market-oriented activities. In addition, export market-oriented activities were positively associated with export performance perspectives.

Leonidou et al. (2002) synthesized extant knowledge based on the export marketing strategyperformance relationships. They reported that although several marketing strategy variables might positively influence on overall export performance, the relationship was not always significant. Moreover, the export performance measures investigated in various studies, stronger effects were detected on export proportion of sales. Asgharnia et al. (2016) determined various decision support system factors influencing on development of export activities on selected firms which are active in Tehran Stock Exchange. Using principle component analysis, they determined five factors including internal resources, management approach, quality of data, efficiency of data and organizational approach, affecting the most on export activities. Jafarinezhad et al. (2016) studied the impacts of customer segmentation factors on the performance of SMEs in Iranian food industry. They selected a sample of people who were involved in development of SMEs in city of Tehran, Iran. And using principal component analysis determined that various factors including competitive structure, organizational strategy, customer's studies and organizational factors maintained the most on promoting export activities. Lotfi and Naami (2015) presented a survey to determine important business intelligence factors affecting on development of export activities. The study determined four factors including competitive position, organizational resources, efficient system and customer orientation influencing on development of export activities.

\section{The proposed study}

The history of steel industry in Iran mainly goes back to the late 1960s when the former Soviet Union planned to build a 600,000-ton steel plant in an exchange for natural gas. In view of the recent geographical redistribution of global iron and steel production and consumption, environmental consideration, as well as shortage of ferrous scrap, Iran's wealth of vast natural gas and other raw materials is important for the industry and a significant trained and inexpensive workforce play an essential role in the domestic and foreign steel markets. Iran's detailed planning and determination, rich mining reserves, creative human resources and an uptrend in domestic and foreign investment may bring Iran among the world's top major steel producers. 
This paper presents an empirical investigation to determine important factors on promoting export. The study designs a questionnaire in Likert scale and distributes it among some experts active in steel industry. Kaiser-Meyer-Olkin Measure of Sampling Adequacy is equal to 0.839 and Bartlett's Test of Sphericity yields an approximation Chi-Square value of 2485.02 (Sig. $=0.000, \mathrm{df}=276$ ). The study uses principle component analysis to extract important factors. Table 1 shows the results of total variance explained.

\section{Table 1}

The summary of total variance explained

\begin{tabular}{cccccccccc}
\hline \multirow{2}{*}{ Component } & \multicolumn{3}{c}{ Initial Eigenvalues } & \multicolumn{3}{c}{ Extraction Sums of Squared Loadings } & \multicolumn{2}{c}{ Rotation Sums of Squared Loadings } \\
\cline { 2 - 10 } & Total & \% of Variance & Cumulative \% & Total & \% of Variance & Cumulative \% & Total & \% of Variance Cumulative \% \\
\hline 1 & 7.601 & 31.671 & 31.671 & 7.601 & 31.671 & 31.671 & 3.976 & 16.565 & 16.565 \\
2 & 3.116 & 12.983 & 44.653 & 3.116 & 12.983 & 44.653 & 3.784 & 15.767 & 32.333 \\
3 & 2.706 & 11.277 & 55.930 & 2.706 & 11.277 & 55.930 & 3.341 & 13.922 & 46.255 \\
4 & 1.838 & 7.659 & 63.589 & 1.838 & 7.659 & 63.589 & 3.147 & 13.111 & 59.366 \\
5 & 1.454 & 6.059 & 69.648 & 1.454 & 6.059 & 69.648 & 2.468 & 10.281 & 69.648 \\
\hline
\end{tabular}

\section{Table 2}

Rotated Component Matrix

\begin{tabular}{|c|c|c|c|c|c|c|}
\hline Question & Attributes & 1 & 2 & 3 & 4 & 5 \\
\hline $\mathrm{q} 10$ & Employee training & .832 & & & & \\
\hline q18 & Establishing appropriate incentive system for shareholders and employees & .821 & & & & \\
\hline q27 & Expansion of research and development & .797 & & & & \\
\hline q3 & Specialization & .766 & & & & \\
\hline q30 & Facilitate in management & .636 & & & .365 & \\
\hline q12 & Knowledge management in organization & .618 & & & & \\
\hline q1 & Productivity in production & & .862 & & & \\
\hline $\mathrm{q} 2$ & Creativity and innovation & & .782 & & & \\
\hline q24 & Performance improvement & & .778 & & & \\
\hline q9 & Quality improvement & & .754 & & & \\
\hline $\mathrm{q} 4$ & Technology improvement & & .745 & & & \\
\hline q29 & Take advantage of free capacities & & .697 & & & \\
\hline $\mathrm{q} 21$ & Being market oriented & & & .931 & & \\
\hline q13 & Process improvement & & & .895 & & \\
\hline q6 & Design and development of new strategies based on market conditions & & & .873 & & \\
\hline q19 & Long-term strategic positioning rather than short-term returns & & & .770 & & \\
\hline q14 & Increased competition between firms involved in exporting & & & & .851 & \\
\hline q16 & Increasing the country's economic stability & & & & .823 & \\
\hline q5 & De-monopolization & & & & .791 & \\
\hline $\mathrm{q} 28$ & Using the gap between demand and supply of finished products & & & & .730 & \\
\hline $\mathrm{q} 23$ & Infrastructure development to attract more domestic and foreign investors & & & & & .860 \\
\hline q7 & Design and development of intelligent information systems & & & & & .802 \\
\hline $\mathrm{q} 31$ & Improving transport channel & & & & & .724 \\
\hline q17 & $\begin{array}{l}\text { Coordination of complementary institutions such as the privatization of } \\
\text { banking, insurance and customs }\end{array}$ & .387 & & .372 & & 471 \\
\hline
\end{tabular}

Using principle component analysis with Varimax rotation, the study has detected five important factors including human resources development, productivity management, marketing management, creating competitive environment and building necessary infrastructures. Table 3 demonstrates the results of Cronbach alpha and factor loadings. Fig. 1 shows the structure of the proposed model where $\mathrm{HR}, \mathrm{PM}, \mathrm{MM}, \mathrm{CE}$ and IN represent human resources, productivity management, marketing management, competitive environment and infrastructure, respectively.

According to the results of Table 3, human resources development (HRD) is the first important factor influencing on export activities, which includes six factors. Training is believed to be one of the 
important issues on HRD category. In fact, when employees have adequate familiarity with export affairs, they will be able to detect target market faster and easier. This must be accompanied by incentive programs to create sufficient motivation for employees and shareholders to participate in any export development activities through expansion on research and development as well as knowledge management in organization. Productivity management is the next factor to boost export activities, which includes six items. Steel industry is a low profit margin industry and there is a high competition in the world. Many countries try to be more effective through offering more cost effective facilities by applying creative ideas, increasing performance and quality improvement, taking advantage of existing unused capacities and technology improvement.

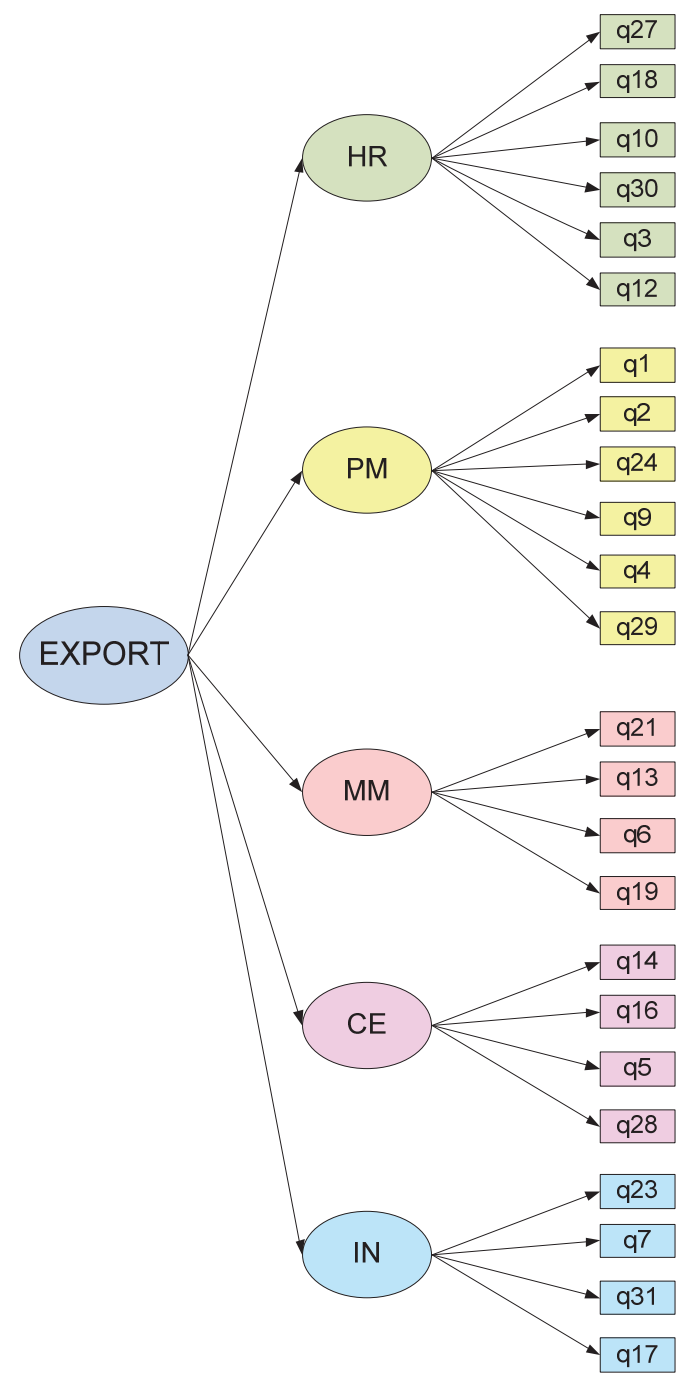

Fig. 1. The proposed model

Marketing management is another important factor influencing on development of export activities. In today's global industry, management team must be familiar with appropriate market oriented activities and process improvement. It is also important to design and develop new strategies based on market conditions and look for long-term strategic positioning rather than short-term returns. Competitive environment is another important factor for development of business activities. Presently, there are limited numbers of steel companies in Iran and government needs to increase competition among them to help export activities. This could happen only by increasing the country's economic stability and by taking advantage of the existing gap between demand and supply of finished products. Finally, having a good and reliable infrastructure plays an important to boost export activities. 
Table 3

The results of principal component analysis

\begin{tabular}{|c|c|c|c|c|c|c|}
\hline Item & Factor & Cronbach & Q. & Attribute & Factor & Rank \\
\hline 1 & \multirow{6}{*}{$\begin{array}{c}\text { Human } \\
\text { resources } \\
\text { development }\end{array}$} & \multirow{6}{*}{0.87} & q10 & Employee training & .832 & 1 \\
\hline 2 & & & $\mathrm{q} 18$ & Establishing appropriate incentive system for shareholders and employees & .821 & 2 \\
\hline 3 & & & $\mathrm{q} 27$ & Expansion of research and development & .797 & 3 \\
\hline 4 & & & $\mathrm{q} 3$ & Specialization & .766 & 4 \\
\hline 5 & & & $\mathrm{q} 30$ & Facilitate in management & .636 & 5 \\
\hline 6 & & & q12 & Knowledge management in organization & 618 & 6 \\
\hline 7 & \multirow{6}{*}{$\begin{array}{l}\text { Productivity } \\
\text { management }\end{array}$} & \multirow{6}{*}{0.79} & $\mathrm{q} 1$ & Productivity in production & .862 & 1 \\
\hline 8 & & & $\mathrm{q} 2$ & Creativity and innovation & .782 & 2 \\
\hline 9 & & & q24 & Performance improvement & .778 & 3 \\
\hline 10 & & & q9 & Quality improvement & .754 & 4 \\
\hline 11 & & & $\mathrm{q} 4$ & Technology improvement & .745 & 5 \\
\hline 12 & & & q29 & Take advantage of free capacities & 697 & 6 \\
\hline 13 & \multirow{4}{*}{$\begin{array}{l}\text { Marketing } \\
\text { management }\end{array}$} & \multirow{4}{*}{0.89} & $\mathrm{q} 21$ & Being market oriented & .931 & 1 \\
\hline 14 & & & q13 & Process improvement & .895 & 2 \\
\hline 15 & & & q6 & Design and development of new strategies based on market conditions & .873 & 3 \\
\hline 16 & & & q19 & Long-term strategic positioning rather than short-term returns & .770 & 4 \\
\hline 17 & \multirow{4}{*}{$\begin{array}{l}\text { Competitive } \\
\text { environment }\end{array}$} & \multirow{4}{*}{0.71} & q14 & Increased competition between firms involved in exporting & .851 & 1 \\
\hline 18 & & & q16 & Increasing the country's economic stability & .823 & 2 \\
\hline 19 & & & q5 & De-monopolization & .791 & 3 \\
\hline 20 & & & $\mathrm{q} 28$ & Using the gap between demand and supply of finished products & .730 & 4 \\
\hline 21 & \multirow{4}{*}{ Infrastructures } & \multirow{4}{*}{0.83} & $\mathrm{q} 23$ & Infrastructure development to attract more domestic and foreign investors & .860 & 1 \\
\hline 22 & & & $\mathrm{q} 7$ & Design and development of intelligent information systems & .802 & 2 \\
\hline 23 & & & q31 & Improving transport channel & .724 & 3 \\
\hline 24 & & & $\mathrm{q} 17$ & $\begin{array}{l}\text { Coordination of complementary institutions such as the privatization of } \\
\text { banking, insurance and customs }\end{array}$ & .471 & 4 \\
\hline
\end{tabular}

\section{Conclusion}

In this paper, we have presented an empirical investigation to determine important factors influencing on development of export activities in Iran. The study has designed a questionnaire and distributed it among some experts in steel industry. Using principle component analysis with Varimax rotation, the study has detected five important factors including human resources development, productivity management, marketing management, creating competitive environment and building necessary infrastructures. The results of this study are consistent with other findings reported by Asgharnia et al. (2016), Baher et al. (2016), Ghasemi et al. (2016).

\section{Acknowledgement}

The authors would like to thank the anonymous referees for constructive comments on earlier version of this paper.

\section{References}

Abedini, R \& Darabi, R. (2015). The effect of private investment, exports, imports, inflation and GDP on per capita premium: Evidence from members of OPEC countries. Management Science Letters, 5(7), 657-662.

Asgharnia, N., Naami, A \& Shoshtari, A. (2016). Decision support systems: Detecting factors influencing on export activities. Uncertain Supply Chain Management, 4(1), 43-48.

Astier J. (1998). The impact of mini-mills in the USA. Ironmaking and Steelmaking, 25(1),7-12.

Baheri, M., Taleghani, V \& Nasiri, P. (2016). Factors influencing business activities for export development. Uncertain Supply Chain Management, 4(1), 17-22. 
Cadogan, J. W., Diamantopoulos, A., \& Siguaw, J. A. (2002). Export market-oriented activities: their antecedents and performance consequences. Journal of International Business Studies, 33(3), 615626.

Farooqui, S. (2016). Bilateral trade and economic growth of China and India: A comparative study.Accounting, 2(3), 117-128.

Ghasemi, A., Eghbal, A \& Toti, H. (2015). Supply chain performance: the role of regional markets. Management Science Letters, 5(5), 487-492.

Habibzadeh, M., Meshkani, F \& Shoshtari, A. (2016). Identifying and ranking the factors affecting entrepreneurial marketing to facilitate exports. Management Science Letters, 6(4), 309-314.

Jafari, M \& Heidari, N. (2011). A survey on decentralized steel industries. Management Science Letters, 1(1), 81-88.

Jafarinezhad, S., Zangeneh, G \& Naami, A. (2016). The effect of customer segmentation factors on export performance of SMEs. Uncertain Supply Chain Management, 4(1), 77-82.

Leonidou, L. C., Katsikeas, C. S., \& Samiee, S. (2002). Marketing strategy determinants of export performance: a meta-analysis. Journal of Business research, 55(1), 51-67.

Lotfi, H \& Naami, A. (2015). Ranking business intelligence factors influencing on development of export. Uncertain Supply Chain Management, 3(3), 225-230.

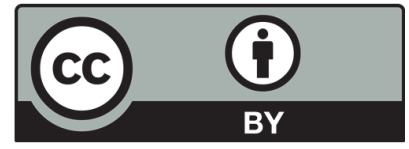

(C) 2016 by the authors; licensee Growing Science, Canada. This is an open access article distributed under the terms and conditions of the Creative Commons Attribution (CC-BY) license (http://creativecommons.org/licenses/by/4.0/). 